\title{
Research on the teaching reform of computer basic course of national preparatory students
}

\author{
Honglong Xie \\ Nanchang institute of science \& technology, China
}

\begin{abstract}
Keywords: national preparatory students, computer basic courses, teaching method, teaching process
\end{abstract}

Abstract. In this paper, we studied the current situation of minority students in computer basic courses in national preparatory education, analyzed some problems and reasons existing in the teaching methods, and put forward some suggestions, in order to be used as a reference for the teaching of other similar schools.

\section{Introduction}

With the constant deepening of the western development, our country payed more and more attention to the computer basic popularization and professional education work of western frontier minority areas. But, the cultural education in western frontier minority areas is relatively backward for a long time, especially the Chinese language level of minority students is lower, and computer basic courses all adopt Chinese textbooks teaching, the contents are very abstract, caused the learning effect is not ideal of computer foundation course for minority preparatory students. If the computer basic course teaching still adopts the same teaching mode with the Han nationality students in colleges and universities, don't concretely analyze the specific issues, in the long run, will seriously affect the basic computer education work of ethnic students in western minority regions.

Computer basic course is referred to as the basic course and bridge course to the university. This course focuses on improving cultural basic knowledge, strengthening basic skill training, to lay a good foundation for students in the undergraduate study. According to the characteristics of the preparatory students, using traditional teaching methods and teaching mode can not meet the need in the process of teaching, so the reform of our computer foundation teaching is imperative, aiming at the difficulties and problems of the preparatory students existed, how to help students overcome these difficulties and improve teaching quality?

\section{The discussion for above questions}

\subsection{Teachers shouldn't complain in the teaching process}

In the actual teaching process, the author heard the individual teachers complain: the class discipline is poor for minority students, the accept ability of knowledge is slow, learning progress can't keep up with the teaching requirements, etc. The author thought that the teachers in the teaching process of these complaints is intolerable, it will only make the teaching effect is not ideal. To this problem, author put forward following two suggestions:

(1) In the process of teaching, should pay attention to the expression of popularization. According to the cognitive characteristics and actual Chinese level of ethnic class students, as far as possible to try to teach the profound theoretical knowledge to easy to understand. For example, to make abstract problems concrete, to make the theory problem visualized. With specific example is given to illustrate theoretical knowledge, make the theory of expression is simple, easy to be understood and accepted by students, then abstract into a general conclusion. For more complex theoretical problems, pay attention to analyze from various angles, to prevent over-generalization, can not be for the sake of easy to understand, and use special instead of general, use concrete instead of abstract, lead to the wrong way of thinking.

(2) Give students a lively and can play to the imagination of classroom atmosphere. Good 
classroom atmosphere can help minority students better understand the course content. They can understand, be in interested and concentrate, classroom discipline is naturally good, thus improves the teaching quality. The author used the above method in the process of practical teaching, has received the good effect.

\subsection{The teaching process can not be "rigid uniformity"}

In the process of actual teaching, because of various reasons, sometimes ethnic students and Han students in a class, ethnic and Han use the same teaching plan, which creates a "rigid uniformity" of ethnic and Han in the teaching process, and this is not conducive to ethnic minority students to learn and absorb professional knowledge. Because the ability of ethnic students to use Chinese language is poor. Computer basic course and other courses have two obvious differences, one is the content is abstract, the second is the content of the understanding and practice is a lot, while these bring great difficulties for ethnic students to learn computer basic course. Ethnic students' ability of using the Chinese language is relative poor, they find it difficult to clearly understand the content which the teachers spoke, and also very hard to put the problems don't understand accurately expressed in Chinese, the teacher must spend a lot of time to clearly know the problems they want to ask, this is a great obstacle to the study of their basic computer courses. To solve above problems, the author put forward the following suggestions:

(1) Try to make the ethnic students class alone as small-class. Teachers must do the teaching design well for ethnic class, elaborate two hours of teaching content, to optimize the whole teaching process. Although teacher speak primarily, but also need to avoid "cramming" education, give full play to the main role of students, pay attention to the students' thinking activities everywhere. At the same time, we should formulate suitable teaching plan and scheduling of the actual situation for minority students.

(2) Classification guidance, differentiated treatment. In the computer foundation course, inspire the minority students with poor foundation, if discovered their flash, need to do more encouragement and praise, to stimulate students' interest and hobby of course. For the students with a solid foundation of learning, better classroom acceptance and understanding, must use high standards and strict requirements, guide these students to see, check and control the "gain" and "loss" of program written by themselves. Practice has proved, classified guidance, the differentiated teaching method can take care of individual minority students and even the whole body, can improve the teaching effect.

\subsection{Should not award or blame too much}

Student has obtained the good learning effect to be obviously and fully affirmed and encouraged, but encourage shall have the discretion to the student, enough is enough, can not award too much, because award too much is bad for students to see their own shortcomings, is not conducive to students to strict demands on themselves, is not conducive to learning progress, so in class, if the students for the knowledge accepting is slower, the teaching except the appropriate encourage and guidance, but should also avoid blaming too much, in order to avoid classroom lifeless, depressed, dampened the enthusiasm of students' learning, leading to students have tired of the psychological, awe of course, affect the teaching effect.

\subsection{Class can not engage in "teacher talk only"}

The vast majority of computer basic courses are using slides teaching now, this caused the teacher to say a lot, but the students rarely hear. At the same time, minority students' Chinese level is uneven, even if teachers speak closely reasoned and well argued, the students are still foggy, some absent-minded even doze, this is the teachers often complained that the "cost tremendous effort has little effect". Therefore, the teacher can according to the characteristics of minority students lively character, use the question type teaching, or arrange some interesting topics that are closely related to the reality, let the students actively through the research of information, help each other to complete.

Therefore, in the process of computer basic teaching, avoid "teacher talk only". Changing the "teacher talk only" into "all have a say", let students appreciate their good comments, comment the insufficient, guide the students dare to put forward different opinions, dare to do the master of class, 
in this way, can receive good effects.

\subsection{Computer should not engage in "hand in hand to tell"}

In the process of teaching, because the class effect of minority students is not ideal, can not operate the computer on the computer class, some teachers have to hand in hand to tell the students how to do with each step. This is a phenomenon of "hand in hand to tell" like a "nanny", is not good for students to understand, grasp and use the basic knowledge of computer.

Computer basis teaching should encourage students to think for themselves, infer other things from one fact, the error that the teacher checked out should guide students to change it, change as little as possible. For this claim, the author has a deep experience. The author taught this chapter of "network application" for minority class, observed that many students interested in this course, often put forward some problems and their ideas to the author. So, pay attention to ability training is very important for students, to enable students to learn how to analyze and solve problems in the new environment.

In the process of the computer, the author intended to let the students to improve the subject has been completed, improved the student's enthusiasm, also cultivated the students' ability of independent thinking and drawing inferences. Therefore, in the process of computer, first teachers must believe students, respect the opinions of the students, don't change the errors that in the process of programming to the end for students, need to use a simple modification method, guide the students to use the learned knowledge in class to solve. At the same time, in the theory class, the teacher can demonstrate some of the errors in the computer class or some better programs, guide students to evaluate the program together, and let everybody put forward his own improvements. In this way, organically combine the practice with theoretical classroom together, in order to achieve a better learning effect.

\subsection{Train the learning interest of student}

Interest is the best teacher, as the saying goes: "those who know it are not as good as those who love it, those who love it are not as good as those who are interested in it", is this truth. When introduce the new knowledge, teachers must impress student, need to set a better case. For example, teach MS Word 2010, first the teacher can show a exquisite blackboard newspaper for students, then decompose this blackboard newspaper into several steps, each step need to pay attention to details. Then let the students to make, for the problems found in the production process, the teacher one by one to guide, if the teacher hands are full, also can let the students with good operating ability to help. Finally lead the students innovative design, through the learned knowledge, combine with their own imagination, to create a new work, throughout the whole process, the students not only can master the knowledge taught in classroom, but also can enhance their own abilities, improve their practical ability, at the same time, enhance the mutual help between students, unity and good learning atmosphere.

Teachers teaching through group discussion teaching method, case teaching method, etc., using different methods for different objects, only one purpose, to let the students interested in basic computer, let the students want to learn, let students feel their achievement.

\section{Conclusion}

Cultivating a large number of information technology talents for ethnic minorities, is one of the major initiatives for the national implementation of the western development strategy, promoting minority economic development and social progress, implementing the party's ethnic policies, strengthening the national unity, maintaining the reunification of the motherland, maintaining national stability and prosperity of all nationalities, is a glorious and noble cause, also is our obligatory responsibility. It is not only an opportunity, but also a challenging work, requires us to go all out and devote ourselves wholeheartedly, and with our love, care, patience and dedication to care for the growth and development of minority students. 


\section{References}

[1] Yongceng Liu. Education innovation awareness and practice [M]. Beijing: China youth publishing house, 2003.

[2] Chunding Yang. Education methodology [M]. Beijing: People's education press, 2000.

[3] Xianhua Zhang.The revolution of education thought [M]. Beijing: Peking University press, 2005. 